\title{
Effects of egonol that isolated from seeds of Styrax officinalis (L.) on lipid peroxidation and antioxidant defense system in human erythrocytes
}

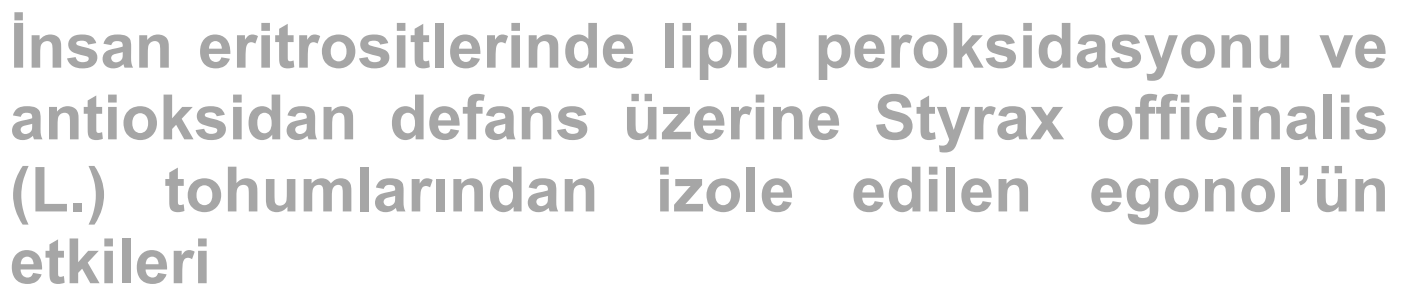

Serap Şahin-Bölüikbaşı1 ${ }^{1}$, Safìye Emirdağ Öztürk ${ }^{2}$, Hüiseyin Anıl², Yavuz Siliğg ${ }^{3}$

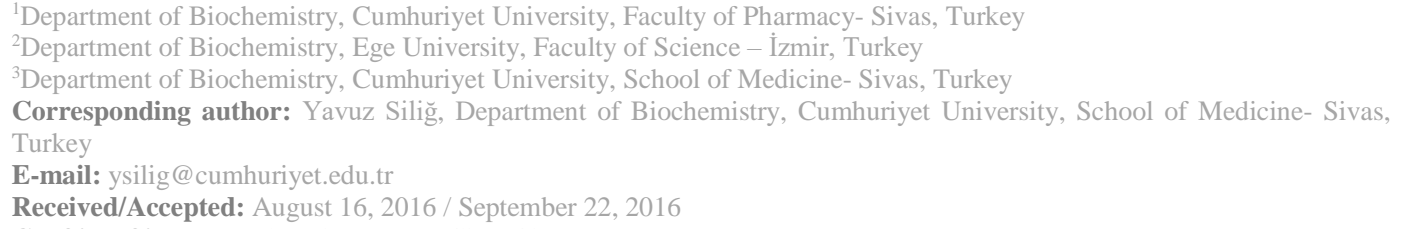

\section{SUMMARY}

Objective: The aim of the present study was to investigate the effects on antioxidant defense system in human erythrocytes exposed to egonol that isolated from seeds of Styrax officinalis $L$.

Method: A solution of Egonol was added so that final concentrations of Egonol were 0.2, 0.4, 0.6, 0.8 , and $1 \mathrm{mg} / \mathrm{ml}$ and erythrocyte pellets were incubated for 15 minutes. Malondialdehyde (MDA) level, activities of glutathione peroxidase (GPx), catalase (CAT), superoxide dismutase (SOD), glutathione-S-transferase (GST) glutathione were determined in hemolysis of human erythrocytes.

Results: Activities of SOD and GST were markedly increased in erythrocyte of human blood compared to the control group $(\mathrm{p}<0.05)$ in all concentrations of egonol. This increase also dosedependent manner. The activities of SOD and GST enzymes were increased $30 \%$ and $70 \%$, respectively, in $1 \mathrm{mg} / \mathrm{ml}$ egonol concentration. There were no statistically significant alterations in GPx and CAT enzyme activities. In addition, MDA level that is an indicator of lipid peroxidation was not found to be increased significantly.

Conclusion: Those results revealed that egonol has no effect of enhancing free radical formation in erythrocyte thus also causes no increase lipid peroxidation was observed. It was observed that, egonol was increased SOD and GST enzymes activities and free radicals were disappeared by the antioxidant defense system so erythrocytes were preserved from the lipid peroxidation.

Keywords: Antioxidant defense system, egonol, human erythrocytes, Styrax officinalis L. 
ÖZET

Amaç: Bu çalışmada; Styrax officinalis L. tohumlarından izole edilen egonolün, insan eritrositleri antioksidan savunma sistemi üzerine etkisinin araştırılması amaçlanmıştır.

Yöntem: Egonolün deney ortamındaki son derişimleri 0.2, 0.4, 0.6, 0.8 ve $1 \mathrm{mg} / \mathrm{ml}$ olacak şekilde eritrositler üzerine eklendi ve eritrosit peletler 15 dakika süreyle inkübe edildi. İnsan eritrosit hemolizatlarında; glutatyon-s-transferaz (GST), katalaz (KAT), süperoksit dismutaz (SOD) ve glutatyon peroksidaz (GPx) enzim aktiviteleri ile malondialdehit (MDA) düzeyleri belirlendi.

Bulgular: Egonol uygulanan insan kan eritrosit grupları, kontrol grubuyla karşılaş̧ırııldığında, SOD ve GST enzim aktivitelerinde doz bağımlı olarak belirgin artı̧̧lar gözlendi $(\mathrm{p}<0.05) .1 \mathrm{mg} / \mathrm{ml}$ egonol derişiminde, SOD ve GST enzim aktivitelerinde sırasıyla, $\% 30$ ve $\% 70$ artış saptandı. GPx ve CAT enzim aktiviteleri arasında istatistiksel olarak anlamlı değişiklikler gözlenmedi. Buna ek olarak, lipid peroksidasyonunun bir göstergesi olan MDA düzeyinde de anlamlı artı̧s saptanmadı.

Sonuç: Bu sonuçlar, egonolün eritrositlerde serbest oksijen radikali oluşumunu arttırıcı bir etkisinin olmamasının yanısıra lipid peroksidasyonunda da artışa neden olmadığını ortaya koymuştur. Egonolün, SOD ve GST enzim aktivitelerini arttırarak, serbest radikallerin antioksidan savunma sistemi tarafindan temizlenmeleri ve eritrositlerin lipid peroksidasyonundan korunmalarına yardımcı olduğu düşünülmektedir.

Anahtar sözcükler: Antioksidan savunma sistemi, egonol, insan eritrosit, Styrax officinalis L

\section{INTRODUCTION}

Styrax officinalis $L$. is a member of the Styracaceae family, which is constituted of small trees and shrubs. It has been found in a region between Palestine and Italy. In Turkey, it grows mainly in northern, southern and western Anatolia ${ }^{1,2}$. Benzofuran, which is found in most plants, especially in the Styracaceae family, such as Styrax japonicum, Styrax formosanus, Styrax obassia, Styrax macranthus and Styrax officinalis, shows a variety of biological activities including insecticidal, fungicidal, antimicrobial, antidiabetic, antiproliferative, and cytotoxic effects ${ }^{1}$. Egonol, a natural 2 -aryl benzofuran, is known to be an effective pyrethrum synergist ${ }^{3}$. Egonol, and its derivatives, attracted the attention of synthetic chemists due to their antibacterial and antifungal ${ }^{4}$, anti-complement ${ }^{5}$ activities besides their considerable cytotoxic activities against human leukaemic HL-60 cells $^{6}$. It was also reported that significant activities were observed for egonol against $\mathrm{C} 6$ (rat glioma) and Hep-2 (larynx epidermoid carcinoma) cell lines ${ }^{7}$. Ozturk S.E. et al. have reported in a study that there were synthesized eighteen derivatives of egonol, and evaluated their antimicrobial activities ${ }^{8,9}$. In recent years, the effect of egonol and its derivatives on cancer and malaria were investigated by Reiter $\mathrm{C}$ et al. This study reported that a cooperative and synergistic effect of the three moieties 1,2,4-trioxane, ferrocene and egonol in hybrid molecule 7 is significant and is obviously stronger than in hybrids $9 \quad(1,2,4-$ trioxaneeferrocene) and 11(artesunic acideegonol), which comprises of only two of the three considered parent compounds ${ }^{10}$.

Epidemiological studies have strongly suggested that diets rich in fruits, vegetables and cereals play a crucial role in the prevention of chronic diseases such as cardiovascular diseases and certain types of cancer by quenching free radicals ${ }^{11-13}$. The beneficial health effects from the consumption of diets rich in fruits and vegetables are mainly due to the presence of antioxidants such as polyphenols, 
carotenoids, anthocyanins and other chemical compounds. Due to their susceptibility to oxidation, erythrocytes have been used as a cellular model to investigate oxidative damage in biomembranes ${ }^{14}$. The oxidative effects of Reactive Oxygen Species (ROS) which include the oxygen free radicals are controlled by non-enzymatic antioxidant defenses, such as vitamins $\mathrm{C}, \mathrm{E}$, and non-protein thiol (NPSH), and also by enzymatic antioxidant defenses, such as scavenger enzymes Superoxide Dismutase (SOD), Catalase (CAT), Glutathione Peroxidase (GPx), and Glutathione Reductase (GR) 15,16 Therefore the aim of the present study was to investigate the effects on the antioxidant defense system in human erythrocytes from exposure to egonol isolated from seeds of Styrax officinalis $L$.

\section{MATERIALS AND METHODS Plant material}

Fruits of $S$. officinalis $L$. were collected from Aydın, Turkey. A voucher specimen was deposited in the Herbarium of Ege University (EGE 4759).

\section{Extraction}

Air-dried and powdered plant material of 241 g. S. officinalis was extracted with n-hexane at room temperature. After filtration, the solvent was removed by rotary evaporation to give a crude extract (113.72 g). An aliquot of the crude was hydrolyzed with $33 \% \mathrm{KOH}$ at $100{ }^{\circ} \mathrm{C}$ for 3 hours. The reaction mixture was collected and extracted with $\mathrm{CH}_{2} \mathrm{Cl}_{2}$, and then the organic phase was subjected to $\mathrm{Si}$-gel $\mathrm{CC}$ to afford egonol. The identification of the achieved $6 \mathrm{~g}$ egonol was done by ${ }^{1} \mathrm{H}$ and ${ }^{13} \mathrm{C}$ NMR.

\section{Egonol}

5-(3'"-chloropropyl)-7-methoxy-2-

(3',4'-methylenedioxyphenyl)

benzofuran. White powder ${ }^{8}$.

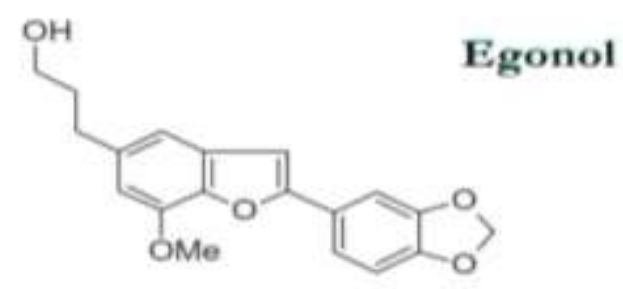

\section{Preparation of erythrocytes suspensions}

Fresh blood (5-10ml) was obtained from normal volunteers via venepuncture after the informed consents were obtained. Those blood samples were centrifuged $(3000 \mathrm{~g}, 10$ min) at $4^{\circ} \mathrm{C}$ using a refrigerated centrifuge (Hettich Rotina 380R), and the plasma and buffy coat were removed by aspiration. The separated erythrocytes were washed four times by centrifugation $(1500 \mathrm{~g}, 5 \mathrm{~min}$ ) in 10 volumes of $10 \mathrm{mM}$ phosphate buffer saline, which consisted of $150 \mathrm{mM}$ $\mathrm{NaCl}$ and $10 \mathrm{mM} \mathrm{NaH} \mathrm{PO}_{4}$ and $\mathrm{Na}_{2} \mathrm{HPO}_{4}$ in deionized water, adjusted to $\mathrm{pH}$ 7.4. The supernatant and buffy coat of white cells was carefully removed with each wash. During the last washing, the erythrocyte suspensions were obtained by centrifugation (1500g, $10 \mathrm{~min})$. Erythrocyte suspensions were finally re-suspended using the same buffer to the desired hematocrit level. Erythrocyte suspensions stored at $4^{\circ} \mathrm{C}$ and used within $6 \mathrm{~h}$ of sample preparation.

\section{Incubation of erythrocytes with egonol}

A solution of egonol, dissolved in DMSO, was added so that the final concentrations of egonol were 0.2 , $0.4,0.6,0.8$, and $1 \mathrm{mg} / \mathrm{ml}$ and 
erythrocyte suspensions were incubated for 15 minutes $\left(37^{\circ} \mathrm{C}\right)$. Erythrocyte suspensions used for the control group incubated at the same conditions without egonol were used as a control assay (Concentrations of DMSO were used similarly for all incubations).

Hemolysis was performed by pipetting $1 \mathrm{ml}$ aliquots of erythrocyte suspensions in a tube containing 28 $\mathrm{ml}$ of hypotonic buffer (20 mOsm, $\mathrm{pH}$ 7.4). The contents were mixed by gentle swirling and then centrifuged at $20,000 \mathrm{~g}$ for $30 \mathrm{~min}$. The supernatant was decanted carefully and the ghost (membrane) was resuspended by adding same strength buffer to reconstitute the original volume. The ghosts were washed three times subsequent to hemolysis ${ }^{17}$. The level of GSH, content of MDA and the activity of SOD, GR, GSH-PX and GST in erythrocytes were measured in this hemolizate. An aliquot of hemolizate was also used for the determination of hemoglobin $(\mathrm{Hb})$ content using colorimetry. Briefly, $8 \mu 1$ of lysate was added into a final volume of $2 \mathrm{ml}$ in Drabkin's solution, and the absorbance of samples was measured against a reagent blank at $540 \mathrm{~nm}$. Hemoglobin was expressed ${ }^{18}$ as $\mathrm{g} / \mathrm{ml}$.

\section{Biochemical assays}

\section{Glutathione-S-transferase Activity}

GST was estimated in $1 \mathrm{ml}$ of incubation mixture containing $500 \mu 1$ of $0.1 \mathrm{M}$ phosphate, buffer ( $\mathrm{pH} 6.5$ ), $75 \mu \mathrm{l} \quad 20 \quad \mathrm{mM}$ 1-chloro-2 4dinitrobenzene (CDNB) reagent, 50 $\mu \mathrm{l}$ of $20 \mathrm{mM}$ GSH and $375 \mu \mathrm{l}$ water preincubated at $37^{\circ} \mathrm{C}$ for $10 \mathrm{~min}$. Reaction was started by adding $50 \mu 1$ of hemolysed. Reaction was followed at $1 \mathrm{~min}$ interval for $5 \mathrm{~min}$ by measuring absorption at $340 \mathrm{~nm}$. Simultaneously, blank was run by substituting deoinize water for homogenate. Then O.D change/min was calculated. GST was estimated by using the molar extinction coefficient $\left[10 \mathrm{mM}^{-1} \mathrm{~cm}^{-1}\right]$ of GST. The results are presented as $\mathrm{U} / \mathrm{mg} \mathrm{Hb}$ 19 .

\section{Catalase activity}

The enzyme activity of Catalase was determined according to the method of Worthington V. (1993). Immediately prior to use, dilute hemolysed of erythrocyte in $0.05 \mathrm{M}$ phosphate buffer ( $\mathrm{pH}$ 7.0) to obtain a rate of 0.03-0.07 $\Delta \mathrm{A} / \mathrm{min}$. Pipette into each cuvette as follows. Take a solution of $1 \mathrm{ml} 0.030 \mathrm{M}$ hydrogen peroxide in $0.05 \mathrm{M}$ potassium phosphate $(\mathrm{pH} 7.0)$ and incubate in spectrophotometer for 4-5 minutes to achieve temperature equilibration and to establish blank rate if any. Add 2.0 $\mathrm{ml}$ of diluted enzyme and record decrease in absorbance at $240 \mathrm{~nm}$ for 2-3 minutes at $25^{\circ} \mathrm{C}$. For blank tube instead of $0.030 \mathrm{M}$ hydrogen peroxide, settle of $1 \mathrm{ml} 0.05 \mathrm{M}$ potassium phosphate ( $\mathrm{pH}$ 7.0). Calculate $\Delta \mathrm{A} 240 / \mathrm{min}$ from the initial (45 second) linear portion of the curve. The results are presented as $\mathrm{U} / \mathrm{mg} \mathrm{Hb}^{20}$.

\section{Superoxide Dismutase Activity}

SOD activity was assayed spectrophotometrically as described by McCord and Fridovich (1969). The reduction of cytochrome $\mathrm{c}$ by superoxide radicals is monitored at $550 \mathrm{~nm}$ utilizing the xanthinexanthine oxidase system as the source for $\mathrm{O}^{-}$. SOD is supposed to complete for superoxidation, and thus decrease the reduction rate of cytochrome c. The standard assay was performed in $3 \mathrm{~mL}$ of $0.05 \mathrm{M}$ potassium phosphate buffer at $(\mathrm{pH}$ 7.8) containing $0.1 \mathrm{mM}$ EDTA in a $1.0 \mathrm{~cm}$ cuvette thermostated at $25^{\circ} \mathrm{C}$. 
The reaction mixture contained $2 \times 10^{-}$ $6 \mathrm{M}$ cytochrome c, 5x $10^{-6} \mathrm{M}$ xanthine, and $0.2 \mathrm{U}$ xanthine oxidase (in $1.0 \times 10^{-4} \mathrm{M}$ EDTA) to produce a rate of reduction of cytochrome $\mathrm{c}$ at $550 \mathrm{~nm}$ of 0.025 absorbance unit per minute. The concentration of xanthine oxidase in the cuvette was usually $6 \times 10^{-9} \mathrm{M}$ but may vary with different preparations of the enzyme. Under these defined conditions, the amount of superoxide dismutase required to inhibit the rate of reduction of cytochrome $\mathrm{c}$ by $50 \%$ (i.e. to a rate of 0.0125 absorbance unit per $\min$ ) is defined as 1 unit of activity. The results are presented as $\mathrm{U} / \mathrm{mg} \mathrm{Hb}^{21}$.

\section{Glutathione peroxidase Activity}

GPx activity was determined by a modified method ${ }^{22}$ of Paglia and Valentine. Activity was determined spectrophotometrically by coupling the oxidation of glutathione and NADPH using Glutathione reductase. Briefly, $1 \mathrm{~mL}$ of assay mixture contained optimized concentrations of the following chemicals: $0.05 \mathrm{M}$ sodium phosphate buffer ( $\mathrm{pH}$ 7.2), 4.3 $\mathrm{mM}$ EDTA, $0.06 \mathrm{U} / \mathrm{mL}$ Glutathione reductase, $4 \mathrm{mM}$ GSH and $0.28 \mathrm{mM}$ reduced NADPH and tissue extract $(0.2 \mathrm{~mL})$. All chemicals were added in the spectrophotometer cuvette along with $0.4 \mathrm{~mL}$ of $0.18 \mathrm{mM}$ cumene hydroperoxide, a suitable substrate for Glutathione peroxidase. The mixture was placed into a $1 \mathrm{~mL}$ cuvette and read with spectrophotometer set at $340 \mathrm{~nm}$ at $37^{\circ} \mathrm{C}$. GP activity was expressed as NADPH mmol oxidized per minute per mg of $\mathrm{Hb}$.

\section{MDA level assay}

Lipid peroxidation was assessed indirectly through the measurement of the thiobarbituric acid (TBA) reaction $^{23}$. One-hundred microlitres of $\mathrm{H}_{3} \mathrm{PO}_{4}(0.44 \quad \mathrm{M})$ and $250 \mu \mathrm{l}$
$(0.67 \%)$ of thiobarbituric acid were added to our $1 \mathrm{ml}$ reaction mixture, and incubated at $95 \mathrm{C}$ for 1 hours. This was then cooled in an ice bath for $10 \mathrm{~min}$ before $150 \mu \mathrm{l}$ of trichloroacetic acid (20\%) was added. After centrifugation at $13,000 \mathrm{rpm}$ for $10 \mathrm{~min}$, the peroxide content of the supernatant obtained was assayed using a TBA reaction with the molar extinction coefficient ( $\left.\mathrm{OD}_{532}\right)$ of MDA. Tetraethoxypropane was used as the standard. MDA values were expressed as $\mathrm{nmol} / \mathrm{mg} \mathrm{Hb}$.

\section{Statistical analysis:}

The significance of differences between control and egonol treated erythrocytes was calculated by student's test. Hypotheses were tested at both the 0.05 and 0.001 levels. p $<0.05$ was taken as significant.

\section{RESULTS AND DISCUSSION}

Egonol has been known to show a variety of biological properties including insecticidal, fungicidal, anti-microbial, anti-diabetic, antiproliferative and cytotoxic. Moreover, egonol has been shown to inhibit the hemolytic activity of the complement system, which could be beneficial in the therapy of inflammatory diseases ${ }^{24}$. However, investigation of its antioxidant properties is quite incomplete. The first time we investigated egonol on lipid peroxidation and antioxidant defense system in human erythrocytes in vitro. Erythrocytes contain high concentrations of polyunsaturated fatty acids, molecular oxygen, ferrous ions in the ligand state; however, they contain cellular antioxidants and enzymes, CAT, SOD GPx and GST 25,26 . Therefore, investigation of the toxicity of different compounds via lipid peroxidation towards erythrocytes is very important ${ }^{27-30}$. 
GST, known as phase II enzymes, are widely distributed catalyzing and binding proteins which promote the conjugation of GSH with a variety of reactive electrophilic compounds resulting in the formation of substances which are easily excreted from the body ${ }^{31-32}$. Several authors have reported that GST is an antioxidant defense and serves to protect the tissues against oxidative ${ }^{33-}$
35. A significant increase was found in GST activity when erythrocytes were treated with egonol at the studied concentrations $(0.2,0.4,0.8,1.0$ $\mathrm{mg} / \mathrm{ml}$ ) when compared to the control groups (19.4, $23.2 \%, 37.2$ and 71.3 $\%)$, respectively $(\mathrm{p}<0.05)$ (Fig. 1). Therefore, under oxidative stress, GST activity is increased in order to cope with the increase in the production of $\operatorname{ROS}^{36}$.

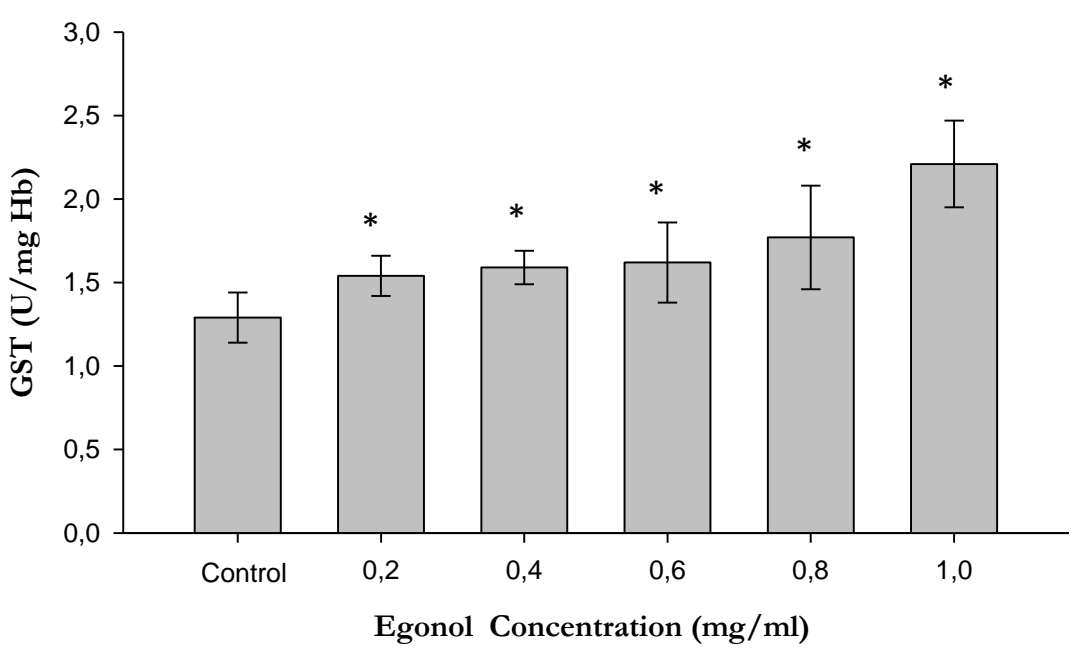

Fig.1 GST activity of human erythrocytes incubated in different concentrations of egonol $(0.2-1.0 \mathrm{mg} / \mathrm{ml})$. Data represent the mean $\pm \mathrm{SD}$ of seven measurements from seven independent experiments. $\mathrm{p}<0.05$ was taken as significant.

SOD and CAT are two important enzymatic antioxidants that act against toxic oxygen free radicals such as superoxide $\left(\mathrm{O}^{-2}\right)$ and hydroxyl ions $(\cdot \mathrm{OH})$ in biological systems. CAT, a soluble protein in erythrocytes, prevents oxidative hazards by catalyzing the formation of $\mathrm{H}_{2} \mathrm{O}$ and $\mathrm{O}_{2}$ from $\mathrm{H}_{2} \mathrm{O}_{2}{ }^{37}$. CAT ( $>0.05$ ) activities were recorded to be not changed when erythrocytes were treated with egonol at the studied concentrations (Fig. 2). 


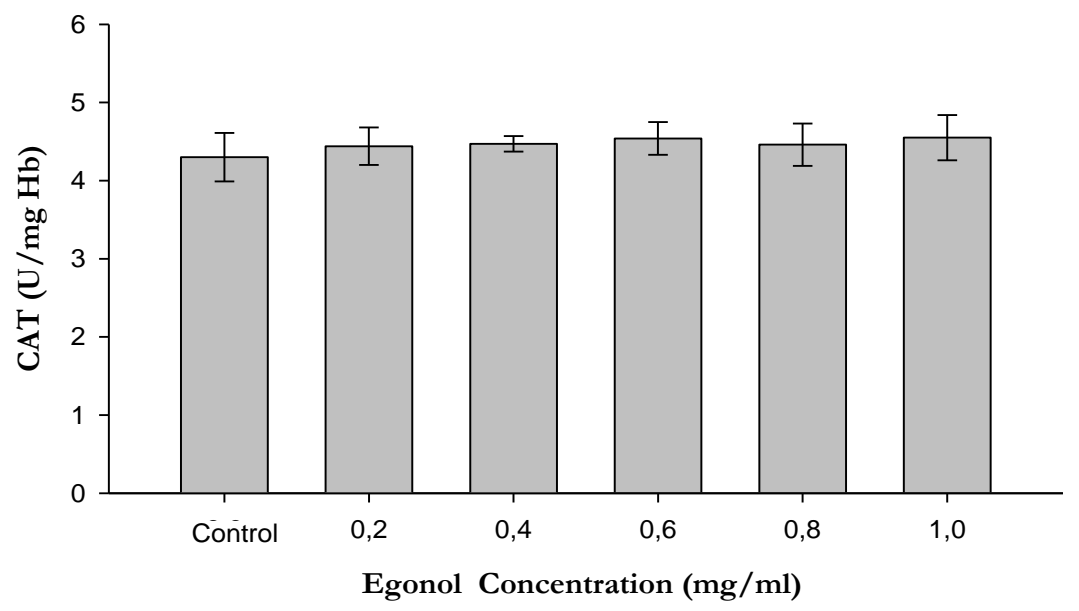

Fig. 2 CAT activity of human erythrocytes incubated in different concentrations of egonol $(0.2-1.0 \mathrm{mg} / \mathrm{ml})$. Data represent the mean $\pm \mathrm{SD}$ of seven measurements from seven independent experiments.

These data show that the induction of SOD, directly mediated by egonol, accelerated the conversion of superoxide radicals to hydrogen peroxide. A significant increase was found in SOD activity when erythrocytes were treated with egonol at the studied concentrations $(0.2,0.4$, $0.8,1.0 \mathrm{mg} / \mathrm{ml}$ ) when compared to the control groups $(7.7,23.4,33.3$ and $43.3 \%$ ), respectively $(\mathrm{p}<0.05)$ (Fig. $3)$.
GPx is an enzyme containing four selenium cofactors that catalyzes the breakdown of $\mathrm{H}_{2} \mathrm{O}_{2}$ and organic hydroperoxides. It also plays a significant role in protecting cells against cytotoxic, peroxidative damage and carcinogenic chemicals by scavenging $\operatorname{ROS}^{32}$. GPx activities were recorded to be not changed when erythrocytes were treated with egonol at the studied concentrations ( $>0.05)$ (Fig. 4).

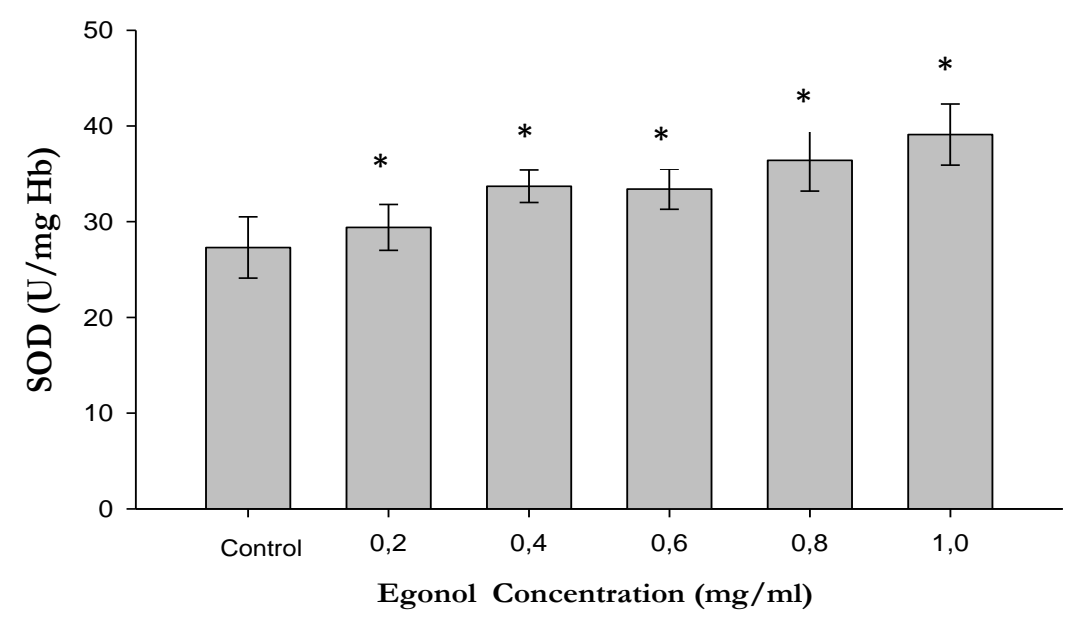

Fig. 3 SOD activity of human erythrocytes incubated in different concentrations of egonol $(0.2-1.0 \mathrm{mg} / \mathrm{ml})$. Data represent the mean $\pm \mathrm{SD}$ of seven measurements from seven independent experiments. $\mathrm{p}<0.05$ was taken as significant. 


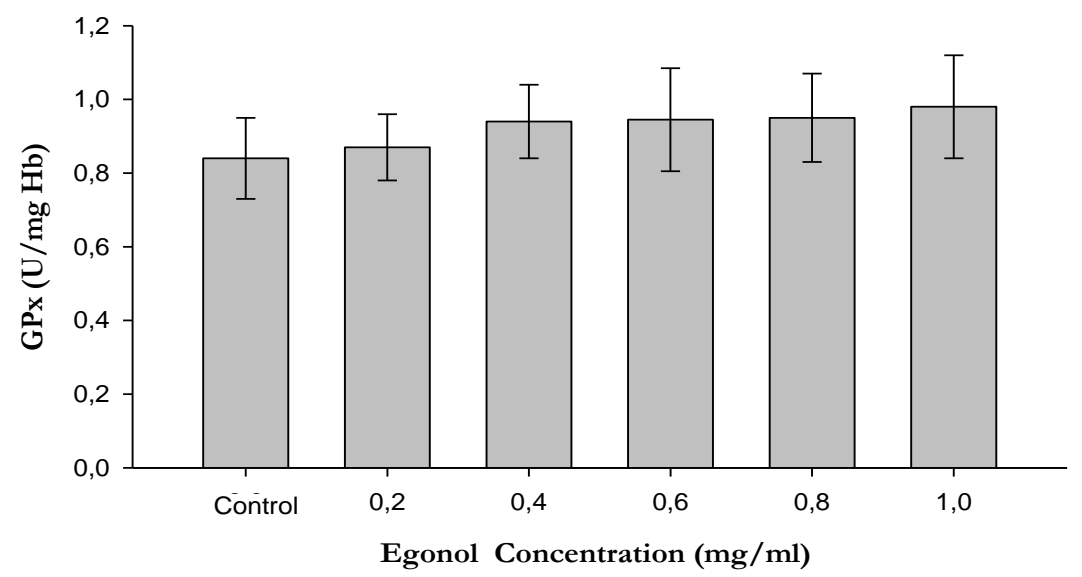

Fig. 4 GPx activity of human erythrocytes incubated in different concentrations of egonol $(0.2-1.0 \mathrm{mg} / \mathrm{ml})$. Data represent the mean $\pm \mathrm{SD}$ of seven measurements from seven independent experiments.

MDA is one of the major oxidation the erythrocytes. There was no products of peroxidized significant change in MDA polyunsaturated fatty acids, and concentrations when erythrocytes increased MDA content is an were treated with egonol at the important indicator of lipid peroxidation $^{39,40}$. Lipid peroxidation studied concentrations $(0.2,0.4,0.8$, is a direct indicator that cell $1.0 \mathrm{mg} / \mathrm{ml})$ as compared with the membrane damage has occurred in control groups ( $\mathrm{p}>0.05)$ (Fig. 5).

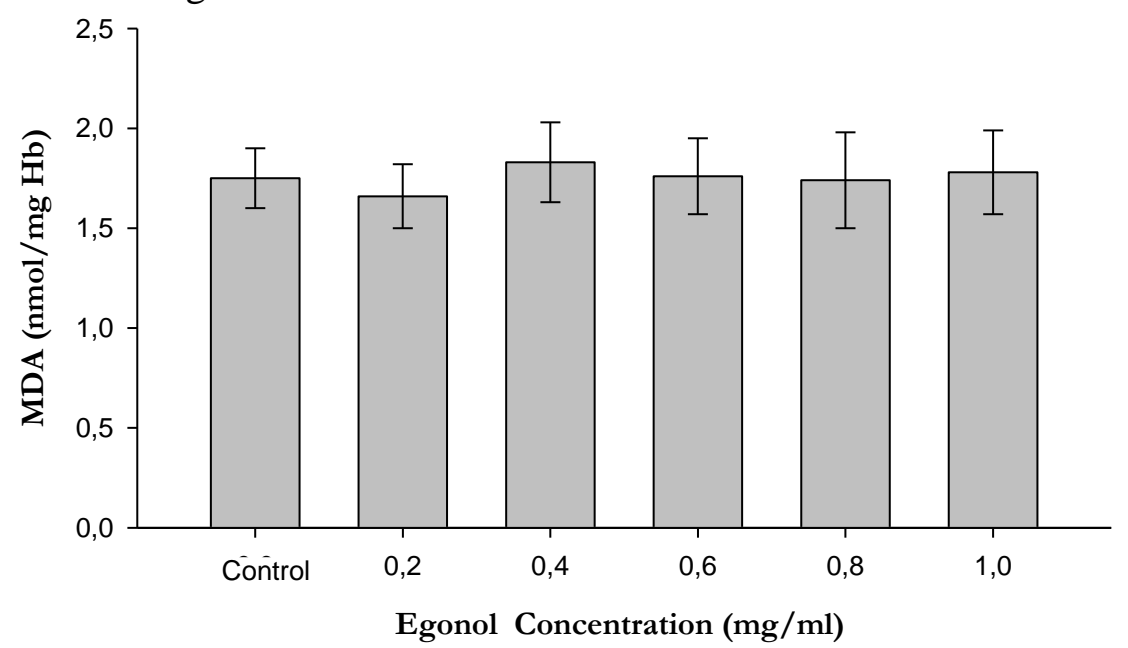

Fig. 5 MDA activity of human erythrocytes incubated in different concentrations of egonol $(0.2-1.0 \mathrm{mg} / \mathrm{ml})$. Data represent the mean $\pm \mathrm{SD}$ of seven measurements from seven independent experiments. 


\section{CONCLUSIONS}

The present study demonstrates a significant increase in GST, SOD activities and unaltered GPx and CAT activity in erythrocytes that were treated with egonol. On the other hand, it has been observed that MDA levels was not changed under the increasing concentrations of egonol in human erythrocytes. Those results revealed that egonol caused a slight formation of free radicals, however, those free radicals were made to disappear by the antioxidant defense system and erythrocytes were preserved from the lipid peroxidation. Future studies are needed to determine the effects of egonol on experimental animals.

\section{Acknowledgements}

This work is supported by the Scientific Research Project Fund of Cumhuriyet University under the project number T-425, Sivas, Turkey

\section{REFERENCES}

1. Davis P H. Flora of Turkey and the East Aegean Islands[M]. Vol. 4. University of Edinburgh Press, Edinburgh: 1972.

2. Vardar V, Oflas S. Preliminary studies on the Styrax oil[J]. S Qual Plant Mater Veg 1973; 22: 145-8.

3. Takanashi M, Takizawa Y. New egonol glycoside having D-xylose from immature seeds of styrax obassia Sieb. et Zucc. J Oleo Sci 2002; 51: 423-6.

4. Pauletti PM, Araújo AR, Young $\mathrm{MC}$, et al. nor-Lignans from the leaves of Styrax ferruyineus (Styracaceae) with antibacterial and antifungal activity [J]. Phytochemistry 2000; 55:597-601

5. Min BS, Na MK, Oh SR, Ahn et al. New furofuran and butyrolactone lignans with antioxidant activity from the stem bark of Styrax japonica [J]. J Nat Prod 2004; 67:1980-4.

6. Hirano $\mathrm{T}$, Gotoh $\mathrm{M}$, Oka K. Natural flavonoids and lignans are potent cytostatic agents against human leukemic HL-60 cells [J]. Life Sci 1994; 55: 1061-9.

7. Teles HL, Hemerly JP, Paulettit $\mathrm{PM}$, et al. Cytotoxic lignans from the stems of Styrax camporum (Styracaceae) [J]. Nat Prod Res 2005; 19: 319-23.

8. Oztürk SE, Akgül Y, Anil H. Synthesis and antibacterial activity of egonol derivatives [J]. Bioorg Med Chem 2008; 16: 4431-7

9. Emirdağ-Öztürk S, Karayildirim T, Anil H. Synthesis of egonol derivatives and their antimicrobial activities [J]. Bioorg Med Chem 2011; 19: 1179-88

10. Reiter C, Capc1 Karagöz A, Fröhlich $\mathrm{T}$, et al. Synthesis and study of cytotoxic activity of $1,2,4-$ trioxane- and egonol-derived hybrid molecules against Plasmodium falciparum and multidrug-resistant human leukemia cells [J]. Eur J Med Chem 2014; 75: 403-12.

11. Miller HE, Rigelhof F, Marquart L, et al. Whole grain products and antioxidants $[\mathrm{J}]$. Cereal Food world 2000; 45: 59-63.

12. Joshipura KJ, Hu FB, Manson JE, et al. The effect of fruit and vegetables intake on risk for coronary heart diseases $[\mathrm{J}]$. Annuals of Internal Medicines 2001; 134: 1106-14.

13. Arouma OI. Methodological consideration for characterizing potential antioxidant actions of bioactive compounds in plant foods $[\mathrm{J}]$. Mutation Research 2003; 9: 523-4. 
14. Sadrazadeh SMH, Graf E, Panter SS, et al. Hemoglobin, a biological Fenton reagent $[\mathrm{J}]$. Journal of Biological Chemistry 1984; 259: 14354-6.

15. McCord JM. Oxygen-derived free radicals in postischemic tissue injury [J]. N Engl J Med. Jan 1985; 312: 159-63.

16. Halliwell B and Gutteridge JMC.

Free radicals in biology and medicine $[\mathrm{M}]$. Clarendon Press.Oxford. 1989.

17. Dodge JT, Mitchell C, Hanahan J. The preparation and chemical characteristics of hemoglobin-free ghosts of human erythrocytes [J]. Archives Biochemistry and Biophysics 1963; 100: 119-30.

18. Drabkin DL. The crystallographic and optical properties of the hemoglobin of man in comparison with those of other species $[\mathrm{J}]$. The Journal of Biological Chemistry 1946; 164: 703-23.

19. Warholm M, Guthenberg C, Bohr $\mathrm{CV}$ et al. Glutathione-STransferases from human liver [J]. Method Enzymol 1985; 113: 499504.

20. McCord JM, Fridovich I. Superoxide Dismutase. An enzymic function for erythrocuprein (hemocuprein) [J]. J Biol Chem 1969; 244: 6049-55.

21. Worthington V. Worthington Enzyme Manual, Catalase, Worthington Biochemical Corporation Freehold, New Jersey, pp.77-80. 1993

22. Paglia DE, Valentine WN. Studies on the quantitative and qualitative characterization of erythrocyte glutathione peroxidase $[\mathrm{J}]$. Lab Clin Med 1967; 70: 158-69.

23. Yagi K. Assay for blood plasma or serum [J]. Methods in Enzymology 1984; 105: 328-31.

24. Min BS, Oh SR, Ahn KS, et al. Anti-complement activity of norlignans and terpenes from the stem bark of Styrax japonica [J]. Planta Med. 2004; 70: 1210-5.

25. Clemens MR, Waller HD. Lipid peroxidation in erythrocytes [J]. Chemistry and Physics of Lipids 1987; 45: 251-68.

26. Ertabak A, Kutluay T, Unlu A, et al. The effect of desferrioxamine on peroxynitrite-induced oxidative damage in erythrocytes $[\mathrm{J}]$. Cell Biochemistry and Function 2004; 22: $149-52$.

27. Akkus I, Gultekin F, Akoz M, et al. Effect of moderate alcohol intake on lipid peroxidation in plasma, erythrocyte and leukocyte and some antioxidant enzymes [J]. Clinica Chimica Acta 1997; 266: 141-7.

28. Orhan H, Sahin G. In vitro effects of NSAIDS and paracetamol on oxidative stres-related parameters of human erythrocytes [J]. Experimental and Toxicologic Pathology 2001; 53: 133-40.

29. Bukowska B, Damage to erythrocytes caused by 2,3,7,8tetrachlorodibenzo-p-dioxin (in vitro) [J]. Cellular Molecular Biology Letters 2004; 9: 261-70.

30. Bukowska B, Kowalska S, Phenol and catechol induce prehemolytic and hemolytic changes in human erythrocytes $[\mathrm{J}]$. Toxicology Letters 2004; 152: 73-84.

31. Chasseaud LF. The role of glutathione and glutathione $\mathrm{S}$ transferases in the metabolism of chemical carcinogens and other electrophilic agents [J]. Adv Cancer Res 1979; 29:175-274.

32. Cervello I, Lafuente A, Giralt M, et al. Enhanced glutathione Stransferase (GST) activity in pregnant rats treated with benzo(a)pyrene $[\mathrm{J}]$. Placenta 1992; 13: 273-80.

33. Mosialou E, Morgenstern R. Activity of rat liver microsomal 
glutathione transferase toward products of lipid peroxidation and studies of the effect of inhibitors on glutathione-dependent protection against lipid peroxidation $[\mathrm{J}]$. Arch Biochem Biophys 1989; 275: 289-94.

34. Hayes JD, Pulford DJ. The glutathione S-transferase supergene family: regulation of GST and the contribution of the isoenzymes to cancer chemoprotection and drug resistance $[\mathrm{J}]$. Crit Rev Biochem Mol 1995; 3: 445-600.

35. Fiander $\mathrm{H}$, Schneider $\mathrm{H}$. Compounds that induce isoforms of glutathione S-transferase with properties of a critical enzyme in defense against oxidative stress [J]. Biochem Bioph Res Co 1999; 262: 591-95.

36. Gutteridge JMC, Halliwell B. Antioxidants: elixirs of life ormedia hype? Antioxidants in nutrition, health and disease, Oxford University Press. 1992; 4062.

37. Halliwell B. Free radicals, antioxidants, and human disease: curiosity, cause, or consequence [J]? Lancet 1994; 344: 721-4.

38. Combs GF, Clark LC. Can dietary selenium modify cancer risk $[\mathrm{J}]$ ? Nutrition Reviews, 1985; 43: 32531.

39. Freeman BA, Crapo JD. Hyperoxia increases oxygen radical production in rat lungs and lung mitochondria[J]. J Biol Chem 1981; 256: 10986-92.

40. Baskaran S, Lakshimi S, Prasad PR. Effect of cigarette smoke on lipid peroxidation and antioxidant enzymes in albino rat $[\mathrm{J}]$. Indian $\mathrm{J}$ Exp Biol 1999; 37: 1196-200. 